\title{
Partial Characterization of Nine Bacteriocins Produced by Lactic Acid Bacteria Isolated from Cold-Smoked Salmon with Activity against Listeria monocytogenes
}

\author{
Elisabetta Tomé ${ }^{1,2}$, Svetoslav D. Todorov ${ }^{3}$, Paul A. Gibbs ${ }^{1,4}$, \\ and Paula C. Teixeira ${ }^{1}$
}

\footnotetext{
${ }^{1}$ Escola Superior de Biotecnologia, Universidade Católica Portuguesa, Porto, Portugal ${ }^{2}$ Instituto de Ciencias y Tecnología de Alimentos, Escuela de Biología, Universidad Central de Venezuela, Caracas, Venezuela

${ }^{3}$ Department of Microbiology, Stellenbosch University, Stellenbosch, South Africa

${ }^{4}$ Leatherhead Food International, Surrey, UK
}

Key Words: cold smoked fish; bacteriocins; lactic acid bacteria; salmon; Listeria monocytogenes

Nine LAB bacteriocin-producers, isolated from vacuum-packaged cold-smoked salmon (CSS), were phenotypically and genotypically identified as Lactobacillus curvatus, Lactobacillus delbrueckii, Lactobacillus fermentum, Enterococcus faecium, and Pediococcus acidilactici. Their bacteriocins were partially characterized. The antimicrobial spectrum was determined against Listeria monocytogenes, $E$. faecalis, E. faecium, and Staphylococcus aureus. The molecular size of bacteriocins ranged from 2.8 to $4.5 \mathrm{kDa}$. They were inactivated by treatment with proteolytic enzymes but not by lipolytic or glycolytic enzymes. Maximal activity against $L$. monocytogenes ranged between 800 and $10000 \mathrm{AU} / \mathrm{mL}$ at $\mathrm{pH}$ 6.5. Most of the bacteriocins maintained full activity in a $\mathrm{pH}$ range of 2.0 to 8.0 but were partially or completely inactivated at $\mathrm{pH} 10.0$. After heating at $60^{\circ} \mathrm{C}$ and $100^{\circ} \mathrm{C}$, only two bacteriocins from $L b$. curvatus strains partially lost activity. All bacteriocins showed a narrow spectrum of activity and a high anti-listerial activity, which is characteristic of the class IIa bacteriocins. Isolated bacteriocinproducing LAB could be used successfully in the bio-preservation of CSS and development of new potential bio-preservatives for CSS active against $L$. monocytogenes.

Address correspondence to Prof. Paula C. Teixeira, Escola Superior de Biotecnologia, Universidade Católica Portuguesa, R. Dr. António Bernardino de Almeida, 4200-072 Porto, Portugal; Tel.: +351 22 5580001; Fax: +351 22 5090351; E-mail: pcteixeira@ esb.ucp.pt 


\section{INTRODUCTION}

The increasing consumer demand for natural food additives has focused interest on bacteriocins. They are ribosomally synthesized peptides of 30 to less than 60 amino acids, with a narrow to wide antibacterial spectrum against Grampositive bacteria (Savadogo et al., 2006). The antibacterial compound is heat stable, and a producer strain displays a degree of specific self-protection against its own antibacterial peptide. Bacteriocins of lactic acid bacteria (LAB) are considered biopreservatives, as it is assumed that bacteriocins are degraded by the proteases of the gastrointestinal tract and most of the LAB are considered as GRAS (Generally Recognized as Safe) microorganisms (Holzapfel et al., 1995).

Although by definition all bacteriocins have a protein or peptide component that is essential for their bactericidal function, some have been reported to consist of combinations of different proteins or are composites of proteins together with lipid or carbohydrate moieties (Jimenez-Diaz et al., 1993). Improved protein purification protocols have shown that some bacteriocins previously considered high-molecular-weight protein aggregates may be small peptides that, because of their highly hydrophobic nature, had previously copurified with some other cellular components (Sahl, 1994). Although some Gram-positive bacteria have been shown to synthesize relatively high-molecularweight, heat-labile bacteriocin-like substances (Vaughan et al., 1994), most of those described to date have been small, heat-stable cationic peptides.

A wide variety of bacterial products of Gram-positive bacteria have been referred to as bacteriocins, and various attempts have been made to classify these agents. Klaenhammer (1993) defined four distinct classes of lactic acid bacterial bacteriocins:

1. Class I, lantibiotics, are small $(<5 \mathrm{kDa})$ peptides containing the unusual amino acids lanthionine (Lan), -methyllanthionine (MeLan), dehydroalanine, and dehydrobutyrine;

2. Class $I I$, small ( $<10-\mathrm{kDa})$, relatively heat-stable, non-lanthionine-containing membrane-active peptides, subdivided into Listeria-active peptides with the N-terminal consensus sequence -Tyr-Gly-Asn-Gly-Val-Xaa-Cys- (Class IIa), poration complexes requiring two different peptides for activity (Class IIb), and thiol-activated peptides requiring reduced cysteine residues for activity (Class IIc);

3. Class III, large (>30-kDa), heat-labile proteins; and

4. Class $I V$, complex bacteriocins that contain essential lipid or carbohydrate moieties in addition to protein. 
In the last decade many bacteriocins from LAB belonging to different groups have been characterized and purified, including nisin, diplococcin, acidophilin, bulgarican, helveticins, lactacins, sacakins, pediocin PA-1, and plantaricins (Nettles and Barefoot, 1993). Of these, nisin produced by Lactococcus lactis subsp. lactis, has been the most extensively characterized (Moreno et al., 2000). At present, nisin is the only bacteriocin commercially available and marketed because it has been conferred GRAS status by the Food and Drug Administration (FDA, 1988; FAO/WHO, 2006).

Only bacteriocins well characterized could be considered as potential natural food preservatives (De Vuyst and Vandamme, 1994). Therefore, the aim of this study was to isolate and identify potential bacteriocin producing LAB from CSS and to characterize the inhibitory activities of these bacteriocins.

\section{MATERIAL AND METHODS}

\section{Fish Source}

Fresh-gutted farmed salmon from Norway (Salmo salar) were acquired at Matosinhos' Doca (Porto, Portugal). Salmon arrived by lorry (72 h travel) in a chilled container with the temperature controlled between $0^{\circ} \mathrm{C}$ and $4^{\circ} \mathrm{C}$ inside polystyrene boxes (two layers of fish between two layers of ice). The fish were transported to the ESB/UCP, under chilled conditions, and submitted to a cold-smoking process (filleted, salted by brining or dry salt method, rinsed, smoked and vacuum-packaged).

\section{Smoking Process}

During salting, fillets were placed in a chilled chamber at $5^{\circ} \mathrm{C}$. For drysalting, the salt and sugar added corresponded to one third of the weight of fillet. For brining, $80 \%$ of saturated $\mathrm{NaCl}$ solution was used (brine/fish: 1/1). Draining was done overnight at $5^{\circ} \mathrm{C}$. Smoking was done by two different processes. The first process consisted of drying for $2 \mathrm{~h}$ in the smoke chamber but without smoke at less than $30^{\circ} \mathrm{C}$, followed by smoking for $6 \mathrm{~h}$ at less than $30^{\circ} \mathrm{C}$. The second process involved drying for $6 \mathrm{~h}$ in the smoke chamber but without smoke at less than $30^{\circ} \mathrm{C}$ and smoking for $2 \mathrm{~h}$. According to Tomé et al. (2007), these drying/smoking conditions enhance growth of total LAB and lactobacilli during the storage period in these products.

Two batches were processed for each smoking process. Each batch consisted of three salmon and three fillets processed in each smoking process.

The smoked samples were cooled overnight at $5^{\circ} \mathrm{C}$. The following day, lug and pin bones and belly flaps were removed and the fillets were then sliced and vacuum packed in a Multivac-Gastrovac (Multivac Sepp Haggenmüller $\mathrm{KG}$, A300/41/42, Germany) 1 mbar/10 s. The permeability of the packs to $\mathrm{O}_{2}$, 
$\mathrm{CO}_{2}$ and $\mathrm{N}_{2}$ were $4 \mathrm{~mol} / \mathrm{m}^{2}$.d.bar., $13 \mathrm{~mol} / \mathrm{m}^{2}$.d.bar, and $4 \mathrm{~mol} / \mathrm{m}^{2}$.d.bar, respectively (Vaz-Velho, 2000). Packs were stored for 3 weeks at $5^{\circ} \mathrm{C}$ and analyzed at the beginning $\left(t_{0}\right)$ and at the end of the storage period $\left(t_{1}\right)$.

\section{Isolation and Phenotypic Characterization of Microorganisms}

At the beginning of storage, $t_{0}$, and after three weeks, $t_{1}$, fillets from each smoking process were cut into small pieces and mixed. Ten grams of this mix were picked randomly and homogenized in $90 \mathrm{~mL}$ of sterile $1 / 4$-strength Ringer's solution (Lab M, Bury, UK) for 2 min in a Stomacher 400 Lab Blender (Seward Medical, London, UK). Serial decimal dilutions in 1/4-strength Ringer's solution were prepared. Three independent samples per batch/smoking process were analyzed at each time interval. Total LAB were enumerated by pour-plating in nitrite actidione polymyxin (NAP) agar, pH 6.7 (Davidson and Cronin, 1973). All colonies were counted as presumptive LAB after 5 days of anaerobic incubation at $25^{\circ} \mathrm{C}$. At $\mathrm{t}_{0}$ and $\mathrm{t}_{1}, 10 \%$ of colonies overall were picked randomly from NAP plates containing 10-100 colonies. Presumptive LAB were subcultured on NAP agar without selective agents or on All-Purpose Tween (APT, Difco Laboratories, Detroit, Mich., USA) agar, examined for purity and characterized using Gram stain, cytochrome oxidase, and catalase tests. Organisms that were Gram-positive, cytochrome oxidase negative, and catalase negative were stored in APT broth with glycerol $(30 \% \mathrm{v} / \mathrm{v})$ at $-80^{\circ} \mathrm{C}$ until further use.

\section{Anti-listerial Activity of LAB, Nature of the Inhibition and Titre Determination}

The antimicrobial activity of 614 presumptive LAB colonies picked from NAP plates, previously isolated from vacuum-packaged CSS was investigated against $L$. monocytogenes 54 (culture collection from ESB/UCP, Porto, Portugal) and L. innocua 2030c (Central Public Health Laboratory, Colindale, London, UK), a tetracycline resistant strain, using the spot method described by Tomé et al. (2006). Then, a $48 \mathrm{~h}$-old culture in APT broth at $25^{\circ} \mathrm{C}$ was made of each $\mathrm{LAB}$ culture showing defined inhibition zones, $\geq 4 \mathrm{~mm}$ zone width. Cultures were adjusted to $\mathrm{pH} 6.5$ with $\mathrm{NaOH}(1 \mathrm{~N})$, and cells were collected by centrifugation ( $7500 \mathrm{x} \mathrm{g}, 10 \mathrm{~min}, 4^{\circ} \mathrm{C}$ ) followed by filtration of the supernatant through a $0.22 \mu \mathrm{m}$ pore size membrane filter (Millipore Co., Bedford, Mass., USA). This solution was designated as a crude filtrate supernatant fluid (CFSF). The nature of the inhibition was assessed by treating the CFSF with the enzymes catalase and trypsin (both from Sigma-Aldrich Chemie GmbH, Steinheim, Germany) separately at a final concentration of $500 \mathrm{IU} / \mathrm{mL}$ and $0.1 \mathrm{mg} / \mathrm{mL}$, respectively, for $2 \mathrm{~h}$ at $37^{\circ} \mathrm{C}$. Cell-free supernatant (CFSF), CFSF treated with catalase and trypsin were spotted against $L$. monocytogenes 54 and L. innocua 2030c. Untreated samples were used as positive controls while enzyme solutions were used as 
negative controls. The anti-listerial titre of each CFSF was determined against L. monocytogenes 54 by the serial twofold dilution assay. It was defined as the reciprocal of the highest dilution showing a distinct inhibition of the target strain and expressed in terms of arbitrary units per milliliter (AU/mL).

\section{Strain Identification}

The carbohydrate fermentation pattern of 9 bacteriocin-producing LAB strains was determined by using the API 50 CHL kit (BioMérieux, Mercy-l'Etoile, France). Coccoid strains, were submitted to some characteristic tests for Enterococcus spp. for example, the ability to grow at $10^{\circ} \mathrm{C}$ and $45^{\circ} \mathrm{C}$ in Tryptone Soy Broth (TSB, Lab M), growth at pH 9.0 and growth in TSB in the presence of $6.5 \%(\mathrm{w} / \mathrm{v}) \mathrm{NaCl}$ at $30^{\circ} \mathrm{C}$. The Vitek System (BioMérieux) was used for species identification of those strains which were able to grow at $10^{\circ} \mathrm{C}$ and $45^{\circ} \mathrm{C}$ and in the presence of $6.5 \%(\mathrm{w} / \mathrm{v})$ of $\mathrm{NaCl}$, using the Gram-Positive Identification Cards (GPI) according to the manufacturer's instructions.

Identification of all nine strains was genotypically confirmed by using genus/species specific PCR amplification. Each strain was cultured overnight in de Man, Rogosa, and Sharpe (MRS) broth (Merck, Darmstadt, Germany) supplemented with $0.4 \%$ DL-threonine (Sigma) at $30^{\circ} \mathrm{C}$, and then the DNA was extracted according to Dellaglio et al. (1973).

Strains were further identified using specific-species primers (Table 1). The PCR reactions were performed in a thermal cycler (My Cycler ${ }^{\text {TM }}$ Thermal Cycler Firware, Bio-Rad, Richmond, Calif., USA) in a total volume of $20 \mu \mathrm{L}$ according Ke et al. (1999), Berthier and Ehrlich (1988), Tilsala-Timisjarvi and Alantossova (1997), Mora et al. (1997), and Chagnand et al. (2001). PCR products were separated by electrophoresis $(100 \mathrm{~V})$ in agarose gel ( $2 \%$ agarose gel for Enterococcus spp. and Lb. curvatus, and 0.8\% agarose gel for Pediococcus spp. and $L b$. fermentum) (Qbiogene, Illkirch, France) in 2M Tris-Acetate-0.05M

Table 1: PCR primers used for genus/species specific PCR amplification.

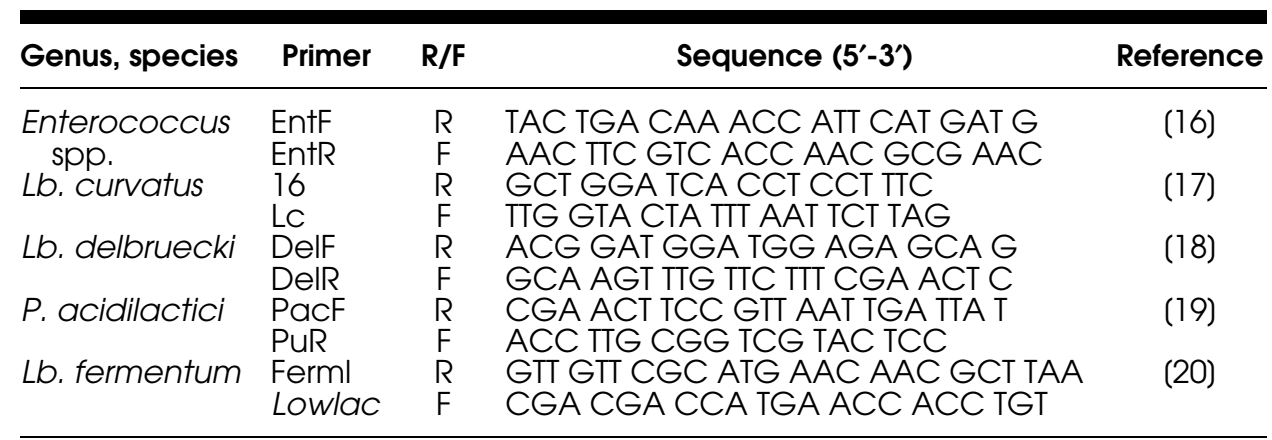

Primers were acquired from Operon Biotechnologies $\mathrm{GmbH}$ (Cologne, Germany). 
EDTA buffer and then stained with $0.5 \mu \mathrm{g} / \mathrm{mL}$ of ethidium bromide in deionized water. A 50-bp DNA or 100-bp DNA ladder (only for Lb. curvatus strains; Jules $^{\text {TM }}$, Qbiogene) was used as molecular size marker. Strains E. mundtii PTA7278 (American Type Culture Collection) and E. faecium HKLHS (CCSU); Lb. curvatus NCFB 2739T (National Collection of Food Bacteria); Lb. delbrueckii subsp. delbrueckii ATCC 9649; P. acidilactici ATCC 12697; Lb. fermentum ATCC 8289 were used as positive controls in specific genus/species PCR amplification reaction for Enterococcus strains (ET05, ET12, ET88), Lb. curvatus strains (ET06, ET30; ET31); Lb. delbrueckii (ET32); P. acidilactici (ET34) and Lb. fermentum (ET35) identification, respectively. Lb. brevis ATCC 14869, and Lb. plantarum ATCC $14917^{\mathrm{T}}$ were used as negative control strains.

\section{Molecular Size of the Bacteriocins}

The molecular size of the bacteriocins from LAB ET05, ET06, ET12, ET30, ET31, ET32, ET34, ET35, and ET88 was determined by tricine-SDS-PAGE according the method described by Schagger and Von Jagow (1987). All strains were grown in MRS broth for $20 \mathrm{~h}$ at $30^{\circ} \mathrm{C}$. The cells were harvested by centrifugation $\left(8000 \mathrm{x} \mathrm{g}, 10 \mathrm{~min}, 4^{\circ} \mathrm{C}\right)$ and the bacteriocin precipitated from the cell-free supernatant with $70 \%$ saturated ammonium sulphate. The precipitate was resuspended in one tenth of the initial volume, in $25 \mathrm{mM}$ ammonium acetate buffer ( $\mathrm{pH}$ 6.5), desalted by using a 1000 Da cut-off dialysis membrane (Spectrum Inc., Oakland, Calif., USA) and separated by tricine-SDS-PAGE. A low molecular weight marker with sizes ranging from 2.5 to $4.5 \mathrm{kDa}$ (Amersham International, Amersham, UK) was used. The gels were fixed and one half of each was stained with Coomassie Blue R250 (Saarchem, Krugersdorp, South Africa), and the other half remained unstained. The position of the active peptide band in the gel was determined by overlaying an unstained gel with cells of L. innocua 2030c (10 $\left.{ }^{6} \mathrm{CFU} / \mathrm{mL}\right)$ suspended in Brain Heart Infusion (BHI, Oxoid Ltd., Cambridge, UK) agar and incubated at $30^{\circ} \mathrm{C}$ for $24 \mathrm{~h}$.

\section{Characterization of Crude Filtrate Supernatant Fluid (CFSF)}

\section{Sensitivity to Enzymes}

To test the sensitivity of the CFSF to the enzymes, samples of $1 \mathrm{~mL}$ were treated for $2 \mathrm{~h}$ at $37^{\circ} \mathrm{C}$ with the following filter-sterilized enzyme solutions, at a final concentration of $0.1 \mathrm{mg} / \mathrm{mL}$, (v/v, 1/1): proteinase $\mathrm{K}$ in $20 \mathrm{mM}$ Tris - HCl, $\mathrm{pH}$ 7.0; trypsin in $40 \mathrm{mM}$ Tris- $\mathrm{HCl}, \mathrm{pH} 8.2$; protease E in $20 \mathrm{mM}$ Tris-HCl, pH 7.4; pepsin A in $20 \mathrm{mM}$ buffer $\mathrm{Na}_{2} \mathrm{HPO}_{4}$, pH 2.8; lysozyme in $20 \mathrm{mM}$ Tris$\mathrm{HCl}, \mathrm{pH} 7.8$, lipase in $0.1 \mathrm{M}$ potassium phosphate, $\mathrm{pH} 6.0$ and $\alpha$-amylase in $20 \mathrm{mM}$ Tris-HCl, $\mathrm{pH} 7.0$ (with the exception of proteinase $\mathrm{K}$ supplied by Boehringer Mannheim GmbH, Germany, all the other enzymes were supplied 
by Sigma). After, residual anti-listerial activity against $L$. monocytogenes 54 (ESB/UCP) was determined. Untreated samples were used as positive controls while enzymes solutions were used as negative controls.

\section{Sensitivity to Different $p H$ Values}

The sensitivity of the CFSF from isolates ET05, ET06, ET12, ET30, ET31, ET32, ET34, ET35, and ET88 to different $\mathrm{pH}$ values was estimated by adjusting each sample to $\mathrm{pH} 2.0$ to $10.0(2.0,4.0,8.0,10.0)$ with $1 \mathrm{~N} \mathrm{NaOH}$ or $1 \mathrm{~N} \mathrm{HCl}$. After incubation at $10^{\circ} \mathrm{C}$ for $24 \mathrm{~h}$, samples were re-adjusted to $\mathrm{pH} 6.5$, filtered through a $0.22 \mu \mathrm{m}$ pore size filter (Millipore Co). Serial twofold dilutions of each CFSF were spotted $(10 \mu \mathrm{L})$ onto fresh APT plates seeded with $L$. monocytogenes 54 and the antimicrobial titres were calculated. Untreated samples were used as control.

\section{Sensitivity to Heat Treatment}

The effect of temperature on the CFSF from isolates ET05, ET06, ET12, ET30, ET31, ET32, ET34, ET35, and ET88 was ascertained by heating each of the CFSFs to $60^{\circ} \mathrm{C}$ for 0 (control), $10,15,30$, and $60 \mathrm{~min}$, or $100^{\circ} \mathrm{C}$ for 0 (control), $5,10,15$, and $20 \mathrm{~min}$. Residual activity was tested against L. monocytogenes 54 and titres were determined at each temperature and time interval.

\section{Spectrum of Antimicrobial Activity}

The spectrum of activity of the CFSF was tested against a wide range of target strains (Table 2) as well as against the bacteriocin-producing strains and $60 \mathrm{LAB}$ isolated from CSS. These cultures were maintained at $4{ }^{\circ} \mathrm{C}$ on agar slants. The following culture media and growth conditions used were: TSB supplemented with $0.6 \%$ (w/v) Yeast Extract (TSYE) for Listeria spp. $\left(30^{\circ} \mathrm{C}\right)$, BHI for S. aureus and Escherichia coli (both at $30^{\circ} \mathrm{C}$ ), TSB for Salmonella sp. $\left(30^{\circ} \mathrm{C}\right)$, MRS medium for Enterococcus spp. $\left(30^{\circ} \mathrm{C}\right)$, Columbia Agar containing $5 \%(\mathrm{v} / \mathrm{v})$ of sheep blood (BioMerieux, for Campylobacter jejuni $\left(37^{\circ} \mathrm{C}\right.$, microaerophilic atmosphere), and Thiosulfate Citrate Bile Sucrose (TCBS) agar (Merck) for Vibrio parahaemolyticus $\left(25^{\circ} \mathrm{C}\right)$. The determination of the antimicrobial spectrum was performed quantitatively against Listeria spp. and qualitatively against the other microorganisms.

\section{RESULTS}

\section{Anti-listerial Activity, Nature of the Inhibition and Titre Determination}

From 614 presumptive LAB colonies isolated from NAP plates, 93 showed anti-listerial activity. Of these, two LAB cultures were inhibitory by organic 


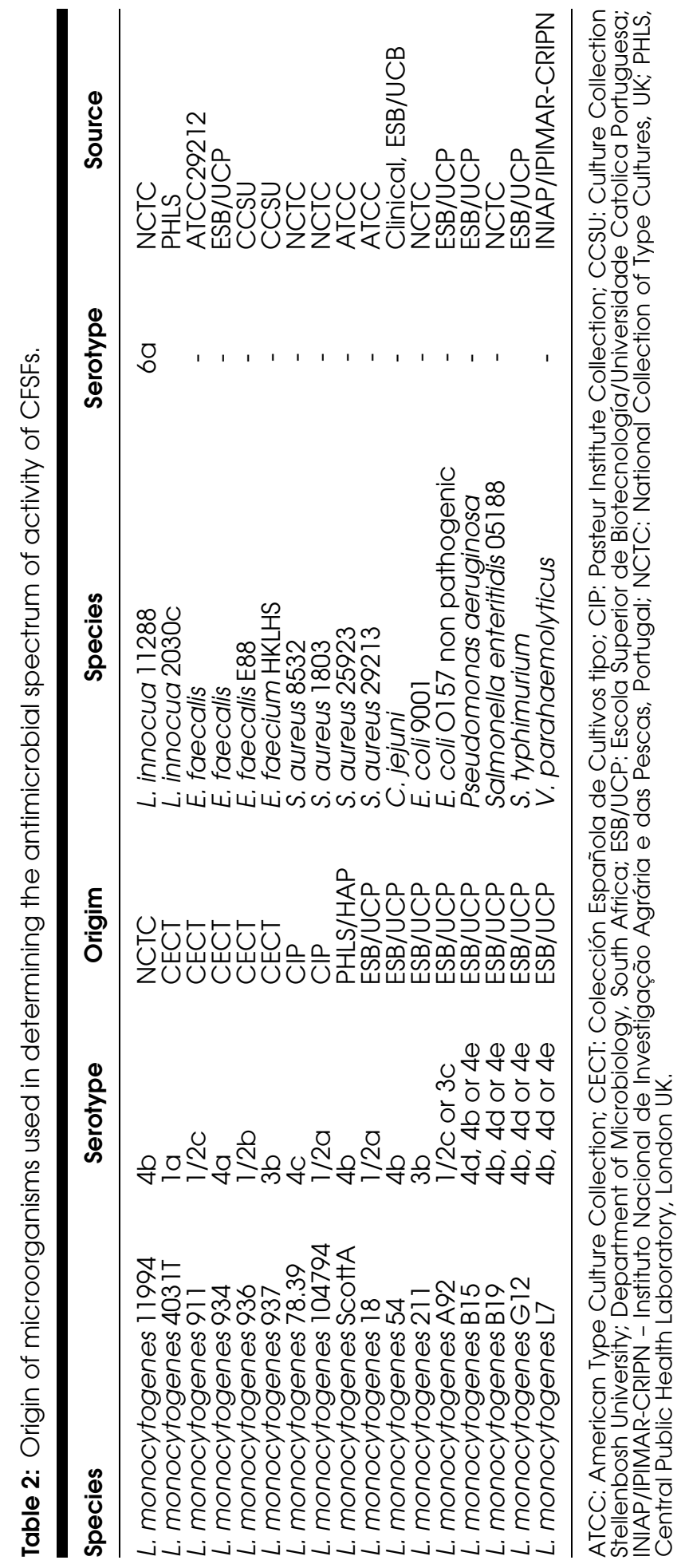


acid production and nine were bacteriocinogenic. The CFSF of these nine bacteriocin-producing strains were able to inhibit L. monocytogenes 54 and L. innocua $2030 \mathrm{c}$ in an in vitro assay performed at $25^{\circ} \mathrm{C}$. Anti-listerial activity was not lost in any of the CFSF either after adjusting their $\mathrm{pH}$ to 6.5 or by catalase treatment. Anti-listerial activity was lost after incubation with trypsin, indicating the proteolytic nature of the nine inhibitory compounds.

The lowest titres were calculated for ET12 and ET88, 800 AU/mL. ET06, ET31, ET34, and ET35 had titres of 1000 AU/mL. ET30 and ET32 had titres of $2000 \mathrm{AU} / \mathrm{mL}$ whilst the highest titre was of $10000 \mathrm{AU} / \mathrm{mL}$, recorded for CFSF ET05.

\section{Strain Identification}

All strains considered as LAB and bacteriocin-producers isolated from vacuum-packaged CSS fillets, were Gram-positive, catalase, and oxidase negative. Isolates ET05, ET12, ET34, and ET88 were cocci, whereas ET06, ET30, ET31, ET32, and ET35 were rods. According to the carbohydrate fermentation patterns of the isolates carried out with the API $50 \mathrm{CHL}$ system (results not shown), all the strains could be successfully identified: ET06, ET30, and ET31 as $L b$. curvatus (\% Id: 98.3; 92.7; 93.3, respectively); ET32 as Lb. delbrueckii (\% Id: 99.6); ET34 as P. pentosaceus (\% Id: 99.9\%); ET35 as Lb. cellobiosus (\% Id: 99.5\%; this species was reclassified recently as $L b$. fermentum). Strains ET05, ET12, and ET88 were identified as members of the genus Enterococcus based on morphology (cocci in pairs), ability to grow in broth at $10^{\circ} \mathrm{C}$ and at $45^{\circ} \mathrm{C}$, at $\mathrm{pH} 9.0$ and in the presence of $6.5 \%$ of $\mathrm{NaCl}$, and by PCR with genus specific primers (results not shown). Further identification to species level, E. faecium, was based on the Gram-Positive Identification Cards, (GPI) from the Vitek System. Identification obtained with API $50 \mathrm{CHL}$ coincided with those obtained by PCR with specific primers for Lb. curvatus (ET06, ET30, ET31, results not shown), Lb. delbrueckii (ET32) and Lb. fermentum (ET35), whilst isolate ET34 identified as $P$. pentosaceus by API 50 CHL, instead was identified as $P$. acidilactici by PCR (results not shown).

\section{Molecular Size of the Bacteriocins}

The molecular size of the nine bacteriocins produced by the LAB strains isolated from vacuum-packaged CSS, ranged from 2.8 to $4.5 \mathrm{kDa}$. Bacteriocins ET05, ET12, ET32, and ET34 from E. faecium strains Lb. delbrueckii strain and $P$. acidilactici strain, respectively, are peptides with molecular weights of approximately $3.5 \mathrm{kDa}$ (Fig. 1A and B). Bacteriocins ET88 and ET35 from $E$. faecium and $L b$. fermentum have molecular weights of approximately $3.7 \mathrm{kDa}$ and $4.0 \mathrm{kDa}$, respectively (Fig. 1C). Bacteriocins ET30 and ET31 from $L b$. curvatus strains had molecular weights of $3.1 \mathrm{kDa}$ and 
(A)

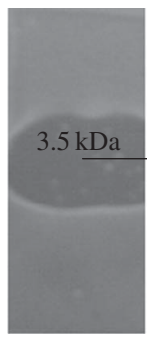

12

(C)

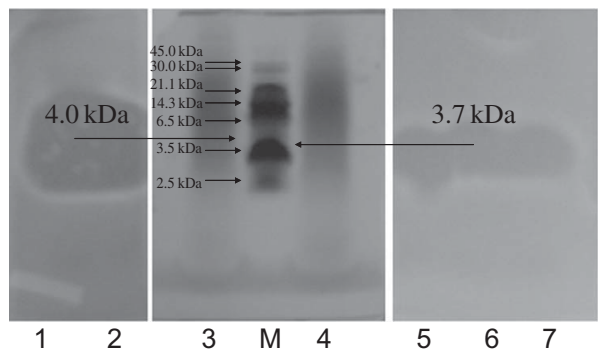

(B)

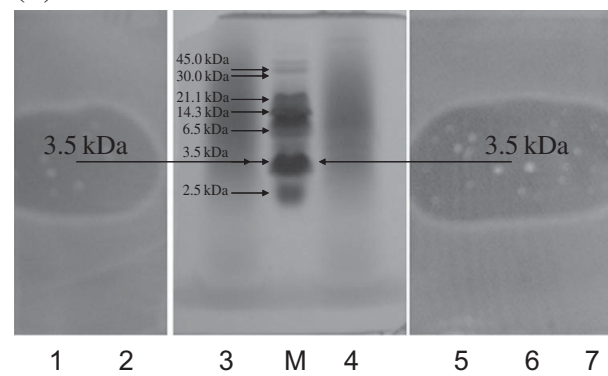

(D)

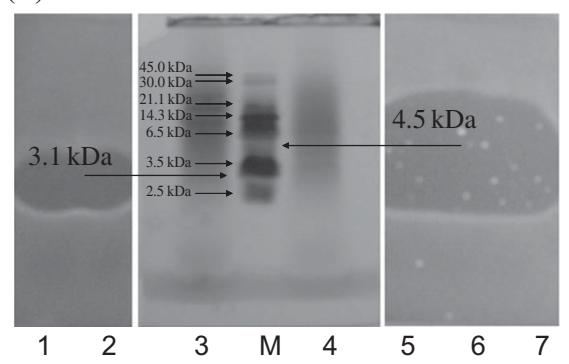

(E)

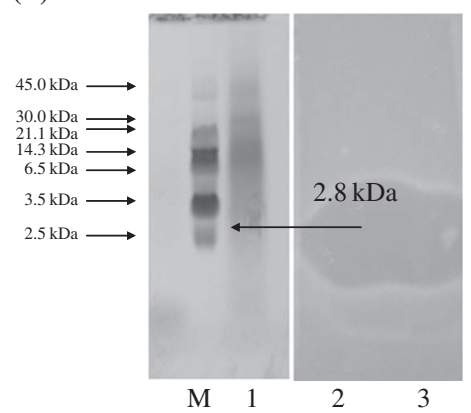

Figure 1: Tricine-SDS-PAGE. (A) Lanes 1-2 and 5-7 = zone of growth inhibition corresponding to the positions of bacteriocins ETO5 and ET12, respectively. Lanes 3 and $4=$ peptide bands stained with Coomassie Blue R250 of bacteriocins ETO5 and ET12, respectively. (B) Lanes 1-2 and 5-7 = zone of growth inhibition corresponding to the positions of bacteriocins ET32 and ET34, respectively. Lanes 3 and 4 = peptide bands stained with Coomassie Blue R250 of bacteriocins ET32 and ET34, respectively. (C) Lanes 1-2 and 5-7 = zone of growth inhibition corresponding to the positions of bacteriocins ET35 and ET88, respectively. Lanes 3 and $4=$ peptide bands stained with Coomassie Blue R250 of bacteriocins ET35 and ET88, respectively. (D) Lanes $1-2$ and 5-7 = zone of growth inhibition corresponding to the positions of bacteriocins ET30 and ET31, respectively. Lanes 3 and $4=$ peptide bands stained with Coomassie Blue R250 of bacteriocins ET30 and ET31, respectively. (E) Lanes 2-3 = zone of growth inhibition corresponding to the positions of bacteriocin ETO6. Lane 1 = peptide bands stained with Coomassie Blue R250 of bacteriocin ETO6. Lane $\mathrm{M}=$ molecular-mass marker (range 2.5 to $45.0 \mathrm{kDa}$; Amersham). The gel was overlaid with L. innocua $2030 \mathrm{c}$ (approximately $10^{6} \mathrm{CFU} \mathrm{mL}^{-1} \mathrm{sus}^{-}$ pended in BHI agar). 
$4.5 \mathrm{kDa}$ respectively (Fig. 1D). Finally bacteriocin ET06, also from a $L b$. curvatus strain, was the smallest peptide with a molecular mass of about $2.8 \mathrm{kDa}$ (Fig. 1E).

\section{Characterization of Crude Filtrate Supernatant Fluid (CFSF)}

\section{a. Sensitivity to Enzymes}

The anti-bacterial activities of all preparations were not affected by catalase, lipase, $\alpha$-amylase or lysozyme but were completely inactivated by the proteolytic enzymes protease $\mathrm{E}$, trypsin and proteinase $\mathrm{K}$ indicating that anti-bacterial activity was associated with proteinaceous sustances. The enzyme pepsin A also inactivated supernatants from $L b$. curvatus strains.

\section{b. Sensitivity to Different $p H$ Values}

The stability of CFSFs in a pH range from 2.0 to 10.0 is shown in Table 3. They differed with regard to their sensitivity to inactivation by changes in $\mathrm{pH}$. Many were stable only in acidic and neutral conditions and were even inactivated at $\mathrm{pH}$ 8.0, for example, CFSF from $L b$. fermentum ET35. Although the nine CFSFs tested were stable at pH 6.5, only CFSF from E. faecium ET05 and $L b$. curvatus ET06 strains remained constant in a wide range of $\mathrm{pH}$ from 2.0 to 8.0. All the other bacteriocins were partly inactivated in the extremes of the $\mathrm{pH}$ range. CFSF activity of $L b$. curvatus ET31, Lb. fermentum ET35 and $E$. faecium ET88 was completely lost at an alkaline $\mathrm{pH}$ while the maximal activity of the others CFSF was reduced to a half.

\section{c. Sensitivity to Heat Treatment}

All CFSFs maintained their antimicrobial activity even at $100^{\circ} \mathrm{C}$ for $20 \mathrm{~min}$. Only CFSFs titres from Lb. curvatus ET30 and ET31 lost 20\% and 50\% of their activities after $10 \mathrm{~min}$ and $30 \mathrm{~min}$ of heating at $60^{\circ} \mathrm{C}$, respectively, and

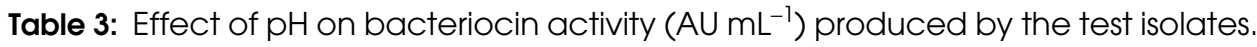

\begin{tabular}{lrrrrrrrrr}
\hline & \multicolumn{10}{c}{ Strains } \\
\cline { 2 - 9 } pH & ET05 & ET06 & ET12 & ET30 & ET31 & ET32 & ET34 & ET35 & ET88 \\
\hline 2 & 10000 & 1000 & 800 & 2000 & 800 & 1600 & 1000 & 500 & 400 \\
4 & 10000 & 1000 & 800 & 2000 & 800 & 1600 & 1000 & 500 & 400 \\
$6.5^{9}$ & 10000 & 1000 & 800 & 2000 & 1000 & 2000 & 1000 & 1000 & 800 \\
8 & 10000 & 1000 & 400 & 1000 & 800 & 1600 & 500 & nd & 400 \\
10 & 1000 & 800 & 400 & 800 & nd & 1600 & 500 & nd & nd \\
\hline
\end{tabular}

aTitre of the CFSF; nd = not detected. 
after $10 \mathrm{~min}$ and less than $5 \mathrm{~min}$ of heating at $100^{\circ} \mathrm{C}$, respectively (titre declined from $2000 \mathrm{AU} / \mathrm{mL}$ to $1000 \mathrm{AU} / \mathrm{mL}$ for the former and from $1000 \mathrm{AU} / \mathrm{mL}$ to $800 \mathrm{AU} / \mathrm{mL}$ for the last one). Then, both maintained their stability during the remaining time of the heating period.

\section{Spectrum of Antimicrobial Activity}

The antagonistic effect of the neutralized and filtered culture supernatants on various Gram-positive bacteria was tested and titres were calculated for each one (Table 4). The inhibition of the various target microorganisms was compared with the inhibitory activity of the nisin-producing Lc. lactis subsp. lactis ATCC 11454. CFSF from this strain presented a wide range of inhibitory spectrum affecting different nontaxonomically related genera like Listeria, Staphylococcus and Enterococcus. Although CFSF from the other bacteriocin-producing strains inhibited a similar but limited range of target microorganisms, there was considerable variability of sensitivities of L. monocytogenes strains inter and intra the nine CFSFs tested. The highest activities $(>10000 \mathrm{AU} / \mathrm{mL})$ were obtained from $E$. faecium (ET05), Lb. curvatus (ET30) and Lc. lactis subsp. lactis ATCC 11454 against practically the same Listeria strains, i.e. L. monocytogenes 11994, L. monocytogenes 934, L. monocytogenes 936, L. monocytogenes Scott A, L. monocytogenes 211, L. monocytogenes G12 and L. innocua 2030c. No inhibitory activity was recorded for CFSF from $L b$. curvatus ET06 against L. monocytogenes 18, L. monocytogenes A92 and L. monocytogenes L7. No relationship seems to exist among the several serotypes of Listeria spp. tested and the level of inhibition obtained. Only CFSFs from Lb. curvatus ET06 and from $L b$. fermentum ET35 were not able to inhibit E. faecalis 29212 and $E$. faecalis (ESB/UCP) while partial or complete inhibition was observed for $E$. faecalis 29212, E. faecalis (ESB/UCP), E. faecalis E88, E. faecium HKLHSE with the others CFSFs. On the other hand, just Lc. lactis subsp. lactis ATCC 11454 showed antimicrobial properties against $S$. aureus strains. None of the CFSFs inhibited any of the Gram-negative strains assessed (results not shown).

The antagonistic activity exhibited by each CFSF against the other bacteriocin-producing strains is recorded in Table 5. Bacteriocin ET31 (Lb. curvatus) showed inhibitory activity against the $E$. faecium strains (weak and reversible against $E$. faecium ET12), while bacteriocins ET06 and ET30 from $L b$. curvatus strains did not show anti-bacterial activities against the same LAB tested. Inhibition by bacteriocins from $E$. faecium was restricted to closely related bacteria, although the antimicrobial compound inhibited Lc. lactis subsp. lactis ATCC 11454. CFSF from Lb. delbrueckii ET32 exhibited activity only against $E$. faecium ET05 while bacteriocin ET35 was inactive against the entire LAB bacteriocin-producing 





Table 5: Antimicrobial spectrum of activity of CFSFs from LAB against the bacteriocin-producing strains.

\begin{tabular}{|c|c|c|c|c|c|c|c|c|c|c|}
\hline \multirow[b]{2}{*}{ Target strains } & \multicolumn{10}{|c|}{ Crude Filtrate Supernatant Fluid (CFSF) } \\
\hline & ET05 & ET06 & ET12 & ET30 & ET31 & ET32 & ET34 & ET35 & ET88 & $\begin{array}{l}\text { L.lactis } \\
\text { ATCC } \\
11454\end{array}$ \\
\hline $\begin{array}{l}\text { E. faecium ET05 } \\
\text { Lb. curvatus ET06 } \\
\text { E. faecium ET112 } \\
\text { Lb. curvatus ET30 } \\
\text { Lb. curvatus ET31 } \\
\text { Lb. delbrueckii ET32 } \\
\text { P. acidilactici ET34 } \\
\text { Lb. fermentum ET35 } \\
\text { E. faecium ET88 } \\
\text { Lc. lactis ATCC } 11454\end{array}$ & $\begin{array}{c}- \\
0 \\
11 \mathrm{~b} \\
0 \\
0 \\
0 \\
0 \\
0 \\
10 \\
8\end{array}$ & $\begin{array}{l}0 * \\
- \\
0 \\
0 \\
0 \\
0 \\
0 \\
0 \\
0 \\
0\end{array}$ & $\begin{array}{l}3 \\
0 \\
- \\
0 \\
0 \\
0 \\
0 \\
0 \\
2^{b} \\
10\end{array}$ & $\begin{array}{l}0 \\
0 \\
0 \\
- \\
0 \\
0 \\
0 \\
0 \\
0 \\
0\end{array}$ & $\begin{array}{l}5 \\
0 \\
5^{\mathrm{b}} \\
0 \\
- \\
0 \\
0 \\
0 \\
8 \\
0\end{array}$ & $\begin{array}{l}3^{b} \\
0 \\
0 \\
0 \\
0 \\
- \\
0 \\
0 \\
0 \\
0\end{array}$ & $\begin{array}{l}5^{b} \\
0 \\
0 \\
0 \\
0 \\
0 \\
- \\
0 \\
0 \\
0\end{array}$ & $\begin{array}{l}0 \\
0 \\
0 \\
0 \\
0 \\
0 \\
0 \\
\overline{0} \\
0\end{array}$ & $\begin{array}{l}4 \\
0 \\
2^{\mathrm{b}} \\
0 \\
0 \\
0 \\
0 \\
0 \\
- \\
4\end{array}$ & $\begin{array}{r}10 \\
0 \\
6 \\
0 \\
0 \\
0 \\
0 \\
0 \\
10 \\
-\end{array}$ \\
\hline
\end{tabular}

*inhibition zone $(\mathrm{mm})$; ${ }^{\mathrm{b}}$ bacteriostatic, reversible within $24-48 \mathrm{~h}$.

bacteria tested. Activity of CFSFs was also screened against 60 LAB isolated from vacuum-packaged CSS; the growth of LAB tested was not inhibited by any of the CFSFs tested.

\section{DISCUSSION}

\section{Strain Identification}

Our results indicated phenotypic heterogeneity and genetic diversity among the vacuum-packaged CSS bacteriocin-producing isolates, with a good correlation between the phenotypic and genetic identification of the strains. As sugar fermentation patterns are not considered to be a reliable method of distinguishing among Enterococcus spp. due to the heterogeneous and atypical profiles displayed by this genus (Pérez et al., 2000), further identification to species level was carried out with the Vitek system, which classified all the enterococcal isolates as $E$. faecium in accordance with the genotypic results at genus level performed by PCR reaction. The fermentation activities recorded with API galleries agreed with those registered with VITEK; however, API $50 \mathrm{CH}$ reactions were not enough to identify microorganisms belonging to Enterococcus genus. On the other hand, the biochemical tests carried out with the GPI cards showed that all the Enterococcus isolated belonged to the same genus/ species $E$. faecium. The genus/species specific PCR identification assay allowed the proper identification of all LAB.

The species identified in our study had been previously isolated from vacuum-packaged CSS or fish products. For instance, González-Rodriguez 
et al. (2002), in a study conducted to assess the microbiological quality of vacuum-packaged CSS produced by various processors in Spain, isolated eight species of Lactobacillus that included a high percentage of Lb. curvatus subsp. curvatus as well as $L b$. delbrueckii subsp. delbrueckii, although this last was a minor proportion. Several strains of Enterococcus spp. were also isolated. Lyhs et al. (1999) isolated Lb. curvatus together with Leuconostoc mesenteroides subsp. mesenteroides, Lb. citreum, Lb. sakei, from spoiled vacuum-packaged, cold-smoked rainbow trout. In contrast, the occurrence of Lb. curvatus in nonspoiled vacuum-packaged salmon has been reported previously by TruelstrupHansen (1995), who identified from 168 LAB, 50\% as Lb. curvatus.

Few reports have recorded the presence of $L b$. fermentum in fish. According to Sharpe and Pettipher (1993), this heterofermentative Lactobacillus specie has predominated in different kinds of spoiled herring. Also, it has been frequently identified in chickens (Reque et al., 2000), a Balinese sausage (Antara et al., 2002), or boza, a traditional Bulgarian fermented beverage (von Mollendorff et al., 2006).

The importance of $P$. acidilactici strains in the food industry is related to their use as starter cultures in fermented meat and vegetable products (Amézquita and Brashears, 2002). This species, like most other LAB species, is involved in extending the shelf life and improving the hygienic quality of various fermented products, via the production of lactic acid and/or the secretion of anti-bacterial compounds such as bacteriocins (Stiles, 1996). The association of pediococci with proteinaceous foods such as fresh and cured meat, and raw sausages has frequently been reported (Holzapfel et al., 2005), and particularly for $P$. acidilactici in fermented sausages (Parente et al., 2001). Pediococcus spp. also have been reported in fresh and marinated fish (Paludan-Muller et al., 2002).

\section{Molecular Size of the Bacteriocins}

Although tricine-SDS-PAGE is not an accurate technique to calculate the molecular mass of molecules, it gives valuable information about the presence of either one or two peptides (Moreno et al., 2002). A single inhibition zone was seen for all the bacteriocins assessed by this technique in this study, although the samples precipitated by ammonium sulphate and analyzed by tricine-SDS-PAGE contained more than one protein band.

Bacteriocins ET05 and ET12 from E. faecium strains ET05 and ET12, respectively, possessed a molecular mass near $3.5 \mathrm{kDa}$ whereas bacteriocin ET88 from E. faecium ET88 has a molecular mass slightly higher. Other enterocins from $E$. faecium strains with close molecular masses have been reported (Moreno et al., 2002) as well as others with higher masses such as enterocin 012 (Jennes et al., 2000). Moreover, strains of E. faecium capable of producing two kinds of bacteriocins with different molecular weights have 
been described, that is, enterocin A, pediocin-like bacteriocin with a molecular weight of $4.8 \mathrm{kDa}$ (Aymerich et al., 1996), and enterocin $\mathrm{B}$, a small nonlantibiotic bacteriocin not belonging to the pediocin group and with a molecular weight of $5.5 \mathrm{kDa}$ (Nilsen et al., 1998).

All the three bacteriocins isolated from $L b$. curvatus strains, named ET06, ET30, and ET31, had different molecular masses. While bacteriocins ET30 and ET06 migrated upon SDS-PAGE gel electrophoresis as small peptides of approximately $3.1 \mathrm{kDa}$ and $2.8 \mathrm{kDa}$ (Fig. 1E), respectively, bacteriocin ET31 had a molecular mass slightly higher $(4.5 \mathrm{kDa}$, Fig. 1D). The molecular weight of curvacin A, the first bacteriocin identified and characterized from a strain of Lb. curvatus, is around $3.0-5.0 \mathrm{kDa}$ (Messens et al., 2002). Like the other bacteriocins assessed here, ET32 from $L b$. delbrueckii ET32 is a small peptide with an apparent molecular size of approximately $3.5 \mathrm{kDa}$ (as estimated by tricine-SDS-PAGE analysis). Although bacteriocins from $L b$. delbrueckii have been rarely described, Boris et al. (2001) characterized a bacteriocin UO004 produced by $L b$. delbrueckii subsp. lactis UO004 with a molecular weight near $6.0 \mathrm{kDa}$ by SDS-PAGE analysis. The molecular mass of the pediocin ET34 was approx. $3.5 \mathrm{kDa}$. Its size is similar to pediocin PD-1 from $P$. damnosus and does not correspond with the molecular mass of the pediocin PA-1 of $4.629 \mathrm{kDa}$ from $P$. acidilactici PAC 1.0 mainly found in fermented sausages and other meat and vegetable fermentations (Jager and Harlander, 1992). Different electrophoretic mobilities of bacteriocins of $L b$. fermentum have been reported; $>1.0 \mathrm{kDa}$ to $<5.0 \mathrm{kDa}$ for Fermenticin B produced by Lb. fermentum Beijerinck CCRC 14018 (Yan and Lee, 1997), $2.3 \mathrm{kDa}-3.0 \mathrm{kDa}$ (von Mollendorff et al., 2006).

Taking into account their bactericidal activity, proteinaceous nature, heat resistance, and low molecular weight, bacteriocins ET05, ET06, ET12, ET32, ET34, ET35, and ET88 can be classified as small, heat-stable Listeria-active peptides possibly belonging to class IIa according to the definition given by Klaenhammer (1993).

\section{Characterization of Crude Filtrate Supernatant Fluid (CFSF)}

\section{a. Sensitivity to Enzymes}

The sensitivity of the inhibitors to enzymes was tested to gain insight into their chemical structure. Results demonstrated that the active moiety of the entire inhibitory substances was not hydrogen peroxide, a lipid, or a glucan, respectively. The loss of anti-bacterial activity of the CFSFs upon treatment with trypsin, protease $\mathrm{E}$, and proteinase $\mathrm{K}$ permits their classification as bacteriocins or/and bacteriocin-like inhibitory substances. The susceptibility of bacteriocins to enzymatic degradation suggests that these peptides will be degraded in the intestinal tract and so will be easily digested without affecting the intestinal flora. From this point of view, Lb. curvatus strains and their 
bacteriocins could be of great interest as bioprotective cultures, because their bacteriocins will be more quickly digested than the other bacteriocins (they are digested by pepsin $\mathrm{A}$, at $\mathrm{pH}$ 2). De Martinis et al. (2003) reported similar bacteriocin sensitivity to these enzymes for the bacteriocins of two strains of $L b$. curvatus isolated from sausages.

The bacteriocins assessed in this study consisted of pure peptides, as their activities were inactivated by treatment with proteolytic enzymes, while lipolytic and glycolytic enzymes had no effect on activity. All of them shared their sensitivity to treatment with proteolytic enzymes but insensitivity to lipolytic and glycolytic enzymes. According to Piard and Desmazeaud (1992), LAB synthesize many bactericidal agents, some of which are bacteriocins with a proteinaceous active moiety and others are nonprotein agents.

\section{b. Sensitivity to Different $p H$ Values}

Bacteriocins differ greatly with regard to their sensitivity to inactivation by changes in $\mathrm{pH}$ and temperature. Many are stable only in acid and neutral conditions, and are even inactivated at $\mathrm{pH}$ 8.0, for example, lactostrepcins, or $\mathrm{pH}$ 10.0, like nisin and pediocin PA-1 (Moreno et al., 2000; Chien-Wei et al., 2004). Most of the bacteriocins maintained full activity over a $\mathrm{pH}$ range of 2.0-8.0 and were partially or completely inactivated at $\mathrm{pH} 10.0$. In this case, the loss of the activity was irreversible and could not be regained upon lowering the $\mathrm{pH}$ to 6.5. Irreversible inactivation can result from a combination of denaturation and chemical modifications of the molecule. The loss of activity can be related to the solubility of the bacteriocins. In the case of enterocins, the isoelectric point of all known enterocins was around 8.3-10.7, which implies that the solubility increases at pHs below the pI. All the nine inhibitory substances showed maximal activity at $\mathrm{pH}$ 6.5. This $\mathrm{pH}$ value is very close to the normal pH of CSS fillets (6.0) (Tomé et al., 2006), which is a positive aspect for the addition of these anti-listerial peptides (or their producing bacteria) into this product.

\section{c. Sensitivity to Heat Treatment}

Bacteriocins were similar with regard to their sensitivity to inactivation by temperature. Like most of the known bacteriocins, they were mainly heattolerant at $\mathrm{pH} 6.5$ (Todorov et al., 1999) after $60 \mathrm{~min}$ of treatment at $60^{\circ} \mathrm{C}$ and $20 \mathrm{~min}$ of treatment at $100^{\circ} \mathrm{C}$. Hill (1994) and Jennes et al. (2000) also reported the heat stability of enterocins. Only bacteriocins ET30 and ET31 were moderately heat-stable at $60^{\circ} \mathrm{C}$ and $100^{\circ} \mathrm{C}$, thus resembling nisin produced by Lc. lactis WNC20 which was inactivated after $15 \mathrm{~min}$ at $121^{\circ} \mathrm{C}$ at $\mathrm{pH} 7.0$ (Noonpakdee et al., 2003) or the pediocin PA-1 showing about $40 \%$ activity lost after $15 \mathrm{~min}$ of heating at $121^{\circ} \mathrm{C}$ in the $\mathrm{pH}$ range $\mathrm{pH} 2.5-9.0$ (Ray, 1994). The moderate stability of the inhibitory peptide produced by $L b$. curvatus strains was previously reported (De Martinis et al., 2003). 


\section{Spectrum of Antimicrobial Activity}

The assessment of the inhibitory spectrum is an important characteristic in order to evaluate the possibility of using the bacteriocin-producing strains or the bacteriocins alone as an additional barrier against spoilage and/or foodborne pathogens in food. Only $2(22 \%)$ out of 9 neutralized culture filtrates displayed activity toward all the Gram-positive microorganisms examined. One characteristic of classical bacteriocins is a narrow spectrum of activity (Tagg et al., 1976). CFSFs of ET05 and ET88 of E. faecium demonstrated the widest antimicrobial spectrum of activity. Moreover it was similar to the inhibitory spectrum of the nisin of Lc. lactis subsp. lactis ATCC 11454, which suppressed the growth of all the Listeria spp. as well as E. faecalis strains, $E$. faecium and $S$. aureus strains. CFSF from $P$. acidilactici ET34 showed an inhibitory spectrum slightly different from those exhibited by the antimicrobial peptide called pediocin $\mathrm{F}$ and pediocin A-1 produced by $P$. acidilactici (Osmanağaoğlu et al., 1998), which is inhibitory to a variety of LAB often encountered in foods, such as Enterococcus, as well as spoilage and pathogenic strains i.e. E. coli and S. aureus. Fimland et al. (2000) showed that the Cterminal disulfide bridge in pediocin-like bacteriocins contributes to widening of the antimicrobial spectrum.

All bacteriocins inhibited strains of $L$. monocytogenes, a pathogen often isolated from a variety of foods. This activity is quite interesting, especially taking into account that many reports showed the occurrence and growth of L. monocytogenes in fish. L. monocytogenes serovar $4 \mathrm{~b}$, which is involved in human infections has been isolated from fresh trout samples (HangardVidaud et al., 1989) as well as smoked salmon. Among the 19 Listeria spp. strains tested, $84.2 \%$ were inhibited by bacteriocin ET06. The high anti-listerial activity displayed by the nine bacteriocins is characteristic of the class IIa bacteriocins (Klaenhammer, 1993; Ennahar et al., 2000). It is interesting to note the resistance of $L$. monocytogenes $18, L$. monocytogenes A92 and L. monocytogenes L7 to bacteriocin ET06. It has been a common observation by bacteriocin researchers that resistance to bacteriocin action is not only species or strain-specific but also dose-dependent. Strains that have the receptors and relevant characteristics of cytoplasmic membrane for proper attachment and sensitivity to the bacteriocin, are generally inhibited (Ennahar et al., 2000).

Our study confirms that $L$. innocua 2030 c resembles $L$. monocytogenes in sensitivity toward LABs ET05, ET06, ET12, ET30, ET31, ET32, ET34, ET35, ET88 bacteriocins and is thus a suitable organism when extensive work with the pathogen is undesirable. On the other hand, the sensitivity differences of each Listeria spp. against the nine CFSFs studied is notable. The highest anti-listerial activity was recorded for CFSF ET05, ET30 and nisin from Lc. lactis subsp lactis ATCC 11454. The dissimilar responses of Listeria spp. to bacteriocins did not appear to be determined either by the serological type 
of the organisms, nor by the growth phase of Listeria strains; all were tested in the stationary phase. As mentioned by Jydegaard et al. (2000), the bacteriocin inactivation of $L$. monocytogenes 412 by nisin and low pediocin concentrations are growth phase dependent, with exponentially growing cells being more susceptible than stationary phase cells. The sensitivity differences of Listeria spp., as well other food-borne and spoilage microorganisms toward diverse bacteriocins have been documented previously by several researchers (Moreno et al., 2000; Coventry et al., 1997; Østergaard et al., 1998). As expected, none of the CFSFs inhibited any of the Gram-negative bacteria evaluated. Activity of bacteriocins against Gram-negative bacteria is unusual and has only been reported for a few bacteriocins of LAB (Caridi, 2002; Todorov and Dicks, 2004a; Todorov and Dicks LMT, 2004b).

Well-defined bacteriocins produced by lactobacilli usually have inhibitory activities restricted to closely related species. However, it is worth noting that CFSFs showed limited activity against other bacteriocin-producer strains (Table 5); just CFSF ET05, ET12 and ET88 exhibited antimicrobial properties toward E. faecium strains and Lc. lactis subsp. lactis ATCC11454, although in some cases this inhibitory activity disappeared within $48 \mathrm{~h}$. CFSF from Lc. lactis subsp. lactis ATCC 11454 such as CFSF ET31 showed limited activity toward bacteria belonging to the genus Enterococcus and no activity at all against the Lactobacillus strains tested. Contrary to what was expected, most of the bacteriocins did not kill species of bacteria that are known to have the same ecological niche. Similar results were reported for pediocin PD-1 produced by $P$. damnosus as it was not active against other pediococci. In that respect, Coventry et al. (1997) pointed out that the sensitivity of Listeria species as well as LAB to bacteriocins may be influenced by the content or type of agar in the growth media. The different inhibition patterns registered for neutralised and filtered culture supernatants of Lb. curvatus strains, against the LAB tested, could suggest that the inhibitory compound produced by $L b$. curvatus ET31 is different from those produced by the other Lb. curvatus strains. These results are promising in view of a recent investigation into the use of combinations of LAB bacteriocins or their producing strains in order to broaden the spectrum to a wide variety of pathogens and food spoilage organisms, and avoid the phenomenon of bacteriocin resistance development, which is the main limiting factor for bacteriocin effectiveness. It is generally admitted that each bacteriocin-sensitive bacterial population includes potentially tolerant and/or resistant cells with structural modifications or at least with a high predisposition to such modifications, which would allow them to spontaneously emerge during exposure to the bacteriocin (Hanlin et al., 1993). In particular, modifications in the cytoplasmic membrane composition are often investigated to explain bacteriocin resistance, considering the key role of the membrane in the activity of bacteriocins (Mazzotta and Montville, 1997). On the other hand, no activity of CFSFs was obtained in the screening assay against 
60 LAB isolated from vacuum-packaged CSS (results not shown). This specificity could be useful for suppressing growth of Listeria in lightly preserved seafood where it could be a serious problem, without interfering with other desirable lactic flora. These results resemble the activity spectrum of the divergicin M35 from Carnobacterium divergens M35, which did not inhibit bacteria belonging to the genera Lactobacillus, Lactococcus, Enterococcus, Pediococcus, Propionibacterium, and Bifidobacterium (Tahiri et al., 2004).

\section{ACKNOWLEDGMENTS}

Financial support to author Tomé was provided by a $\mathrm{PhD}$ fellowship issued by Consejo de Desarrollo Científico y Humanístico de la Universidad Central de Venezuela.

\section{REFERENCES}

Amézquita, A., Brashears, M.M. (2002). Competitive inhibition of Listeria monocytogenes in ready-to-eat meat products by lactic acid bacteria. J. Food Protect. 65:316-325.

Antara, N.S., Sujaya, I.N., Yokota, A., Asano, K., Aryanta, W.R., Tomita, F. (2002). Identification and succession of lactic acid bacteria during fermentation of"urutan," a Balinese indigenous fermented sausage. World J. Microbiol. Biotechnol. 18:255-262.

Aymerich, T., Holo, H., Håvarstein, L.S., Hugas, M., Garriga, M., Nes, I.F. (1996). Biochemical and genetic characterization of enterocin A from Enterococcus faecium, a new antilisterial bacteriocin in the pediocin family of bacteriocins. Appl. Environ. Microbiol. 62:1676-1682.

Berthier, F., Ehrlich, D.S. (1988). Rapid species identification within two groups of closely related lactobacilli using PCR primers that target the 16S/23S rRNA spacer region. FEMS Microbiol. Lett. 161:97-106.

Boris, S., Jiménez-Díaz, R., Caso, L.J., Barbés, C. (2001). Partial characterization of a bacteriocin produced by Lactobacillus delbrueckii subsp. lactis UO004, an intestinal isolate with probiotic potential. J. Appl. Microbiol. 91:328-333.

Caridi, A. (2002). Selection of Escherichia coli-inhibiting strains of Lactobacillus paracasei subsp. paracasei. J. Ind. Microbiol. Biotechnol. 29:303-308.

Chagnaud, P., Machinis, K., Coutte, L.A., Marecat, A., Mereenier, A. (2001). Rapid PCR-based procedure to identify lactic acid bacteria: application to six common Lactobacillus species. J. Microbiol. Meth. 44:139-148.

Chien-Wei, W., Li-Jung, Y., Shann-Tzong, J. (2004). Purification and characterization of bacteriocin from Pediococcus pentosaseus ACCEL. J. Agric. Food. Chem. 52:1146-1151.

Coventry, M.J., Gordon, J.B., Wilcock, A.H., Davidson, B.E., Hickey, M.W., Hiller, A.J., Wan, J. (1997). Detections of bacteriocins of lactic acid bacteria isolated from foods and comparison with pediocin and nisin. J. Appl. Microbiol. 83:248-258.

Davidson, C., Cronin, F. (1973). Medium for the selective enumeration of lactic acid bacteria from foods. J. Appl. Microbiol. 26:439-440. 
De Martinis, E.C.P., Santarosa, P.R., Freitas, F. (2003). Caracterização preliminar de bacteriocinas produzidas por seis cepas de bactérias láticas isoladas de produtos cárneos embalados a vácuo. Ciênc. Tecnol. Alimen. 23:195-199.

De Vuyst, L., Vandamme, E.J. (1994). In: Bacteriocins of Lactic Acid Bacteria; Microbiology, Genetics and Applications. London: Blackie Academic and Professional.

Dellaglio, F., Bottazzi, V., Trovatelli, L.D. (1973). Deoxyribonucleic acid homology and base composition in some thermophilic lactobacilli. J. Gen. Microbiol. 74:289-297.

Ennahar, S., Sashihara, T., Sonomoto, K., Ishizaki, A. (2000). Class IIa bacteriocins: biosynthesis, structure and activity. FEMS Microbiol. Rev. 24:85-106.

[FAO/WHO] Food and Agriculture Organization/World Health Organization . (2006). Summary of Evaluations Performed by the Joint FAO/WHO Expert Committee on Food Additives (JECFA 1956-2005). WashingtonDC: ILSI Press International Life Sciences Institute, 20036-4810.

[FDA] Food and Drug Administration. (1988). Federal Register. Nisin preparation: affirmation of GRAS status as a direct human food ingredient, Fed. Reg. 53, 11247-11251.

Fimland, G., Johnsen, L., Axelsson, L., Brurberg, M.B., Nes, I.F., Eijsink, V.G., NissenMeyer, J. (2000). A C-terminal disulfide bridge in pediocin-like bacteriocins renders bacteriocin activity less temperature dependent and is a major determinant of the antimicrobial spectrum. J. Bacteriol. 182:2643-2648.

González-Rodríguez, M., Sanz, J., Santos, J., Otero, A., García López, M.L. (2002). Numbers and types of microorganisms in vacuum-packed cold-smoked fresh water fish at the retail level. Int. J. Food Microbiol. 36:1-29.

Hangard-Vidaud, N., Nicolas, J.A., Bosgiraud, C., Cormuejols, M.J. (1989). Recherche de Listeria chez les poisons d'eau douce. Microbiol. Alim. Nutr. 7:421-423.

Hanlin, M.B., Kalchayanand, N., Ray, P., Ray, B. (1993). Bacteriocins of lactic acid bacteria in combination have greater antibacterial activity. J. Food Prot. 54: 252-255.

Hill, C. (1994). Enterocin 1146: a bacteriocin produced by Enterococcus faecium DPC1146. In: De Vuyst, L. and Vandamme, E.J., eds. Bacteriocins of Lactic Acid Bacteria. Microbiology, Genetics and Applications. London: Chapman \& Hall, pp. 515-527.

Holzapfel, W.H., Franz, C.M.A.P., Ludwing, W., Back, W., Dicks, L.M.T. (2005). The Genera Pediococcus and Tetragenococcus. In: Dworkin, et al., eds. The Prokaryotes: An Evolving Electronic Resource for the Microbiological Community, third ed., release 3.2. New York: Springer-Verlag.

Holzapfel, W.H., Geisen, R., Schillinger, U. (1995). Biological preservation of foods with reference to protective cultures, bacteriocins and food-grade enzymes. Int. J. Food. Microbiol. 24:343-362.

Jager, K., Harlander, S. (1992). Characterization of a bacteriocin from Pediococcus acidilactici $\mathrm{PC}$ and comparison of bacteriocin-producing strains using molecular typing procedures. Appl. Microbiol. Biotechnol. 37:631-637.

Jennes, W., Dicks, L.M.T., Verwoerd, D.J. (2000). Enterocin 012, a bacteriocin produced by Enterococcus gallinarum isolated from the intestinal tract of ostrich. J. Appl. Microbiol. 88:349-357.

Jimenez-Diaz, R., Rios-Sanchez, R.M., Dezmazeaud, M., Ruiz-Barba, J.L., Piard, J.C. (1993). Plantaricins S and T, two new bacteriocins produced by Lactobacillus plantarum LPCO10 isolated from a green olive fermentation. Appl. Environ. Microbiol. 59:1416-1424.

Jydegaard, A.M., Gravesen, A., Knochel, S. (2000). Growth conditions-related response of Listeria monocytogenes 412 to bacteriocin inactivation. Lett. Appl. Microbiol. 31:68-72. 
Ke, D., Picard, F.J., Martineau, F., Ménard, C., Roy, P.H., Onellette, M., Bergeron, M.G. (1999). Development of a PCR assay for rapid detection of Enterococci. J. Clin. Microbiol. 37:3497-3503.

Klaenhammer, T.R. (1993). Genetics of bacteriocins produced by lactic acid bacteria. FEMS Microbiol. Rev. 12:39-86.

Lyhs, U., Björkroth, J., Korkeala, H. (1999). Characterization of lactic acid bacteria from spoiled, vacuum-packaged, cold-smoked rainbow trout using ribotyping. Int. J. Food Microbiol. 52:77-84.

Mazzotta, A.S., Montville, T.J. (1997). Nisin induces changes in membrane fatty acid composition of Listeria monocytogenes nisi-resistant strains at $10^{\circ} \mathrm{C}$ and $30^{\circ} \mathrm{C}$. J. Appl. Microbiol. 82:32-38.

Messens, W., Verluyten, J., Leroy, F., De Vuyst, L. (2002). Modelling growth and bacteriocin production by Lactobacillus curvatus LTH 1174 in response to temperature and $\mathrm{pH}$ values used for European sausage fermentation processes. Int. J. Food Microbiol. 81:41-52.

Mora, D., Fortina, M.G., Parini, C., Manachini, P.L. (1997). Identification of Pediococcus acidilactici and Pediococcus pentosaceus based on 16S rRNA and ldhD gene-targeted multiplex PCR analysis. FEMS Microbiol. Lett. 151:231-236.

Moreno, I., Lerayer, A.L.S., Baldini, V.L.S., Leitaõ, M.F. (2000). Characterization of bacteriocins produced by Lactococcus lactis strains. Braz. J. Microbiol. 31:84-192.

Moreno, M.R., Leisner, J.J., Tee, L.K., Ley, C., Radu, S., Rusul, G., Vancanney, M., De Vuyst, L. (2002). Microbial analysis of Malaysian tempeh, and characterization of two bacteriocins produced by isolates of Enterococcus faecium. J. Appl. Microbiol. 92:147-157.

Nettles, C.G., Barefoot, S.F. (1993). Biochemical and genetic characteristics of bacteriocins of food-associated lactic acid bacteria. J. Food Prot. 56:338-356.

Nilsen, T., Nes, I.F., Holo, H. (1998). An exported inducer peptide regulates bacteriocin production in Enterococcus faecium CTC492. J. Bacteriol. 174:5686-5692.

Noonpakdee, W., Santivarangkna, C., Jumriangrit, P., Sonomoto, K., Panyim, S. (2003). Isolation of nisin-producing Lactococcus lactis WNC20 strain from nham, a traditional Thai fermented sausage. Int. J. Microbiol. 81:137-145.

Osmanağaoğlu, O., Gündüz, U., Beyatly, Y., Çökmüs, C. (1998). Purification and characterization of Pediocin F, a bacteriocin produced by Pediococcus acidilactici F. Turk. J. Biol. 22:217-228.

Østergaard, A., Embarek, P.K.B., Wedell-Neergaard, C., Huss, H.H., Gram, L. (1998). Characterization of anti-listerial lactic acid bacteria isolated from Thai fermented fish products. Food Microbiol. 15:223-233.

Paludan-Muller, C., Madsen, M., Sophanodora, P., Gram, L., Moller, P.L. (2002). Fermentation and microflora of plaa-som, a Thai fermented fish product prepared with different salt concentrations. Int. J. Food Microbiol. 73:61-70.

Parente, E., Grieco, S., Crudele, M.A. (2001). Phenotypic diversity of lactic acid bacteria isolated from fermented sausages produced in Basilicata (Southern Italy). J. Appl. Microbiol. 90:943-952.

Pérez, G., Cardell, E., Zarate, V. (2000). Protein fingerprinting as a complementary analysis to classical phenotyping for the identification of lactic acid bacteria from Tenerife cheese. Lait 80:589-600.

Piard, J.C., Desmazeaud, M. (1992). Inhibiting factors produced by lactic acid bacteria. Part II. Bacteriocins and other antibacterial substances. Lait 72:113-142. 
Ray, B. (1994). Pediocins of Pediococcus species. In: De Vuyst, L., Vandanme, E.J., eds. Bacteriocins of Lactic Acid Bacteria: Microbiology, Genetics and Applications. London: Chapman and Hall, pp 465-495.

Reque, E., Pandey, A., Franco, S., Soccol, C. (2000). Isolation, identification and physiological study of Lactobacillus fermentum LPB for use as a probiotic in chickens. Braz. J. Microbiol. 31:303-307.

Sahl, H.G. (1994). Staphylococcin 1580 is identical to the lantibiotic epidermin. Implications for the nature of bacteriocins from gram-positive bacteria. Appl. Environ. Microbiol. 60:752-755.

Savadogo, A., Outara, C.A., Bassole, I.H., Traores, A. (2006). Bacteriocins and lactic acid bacteria - a minireview. Afric. J. Biotechnol. 5:678-683.

Schagger, H., Von Jagow, G. (1987). Tricine-sodium dodecyl sulfate-polyacrylamide gel electrophoresis for the separation of proteins in the range from 1 to $100 \mathrm{kDa}$. Anal. Biochem. 166:368-379.

Sharpe, M.E., Pettipher, G.L. (1983). Food spoilage by lactic acid bacteria. Ecol. Microbiol. 8:199-223.

Stiles, M.E. (1996). Biopreservation by lactic acid bacteria. Antonie van Leeuw. 70:331-345.

Tagg, J.R., Dajani, A.S., Wannamaker, L.W. (1976). Bacteriocins of Gram-positive bacteria. Bacteriol. Rev. 40:722-756.

Tahiri, I., Desbiens, M., Benech, R., Kheadr, E., Lacroix, C., Thibault, S., Oullet, D., Fliss, I. (2004). Purification, characterization and amino acid sequencing of divergicin M35: a novel class IIa bacteriocin produced by Carnobacterium divergens M35. Int. J. Food Microbiol. 97:123-136.

Tilsala-Timisjarvi, A., Alatossava, T. (1997). Development of ologonucleotide primers from 16S-23S rRNA intergenic sequence for identifying different dairy and probiotic lactic acid bacteria. Int. J. Food Microbiol. 35:49-56.

Todorov, S., Onno, B., Sorokin, O., Chobert, J.M., Ivanova, I., Dousset, X. (1999). Detection and characterization of a novel antibacterial substance produced by Lactobacillus plantarum ST31 isolated from sourdough. Int. J. Food Microbiol. 48:167-177.

Todorov, S.D., Dicks, L.M.T. (2004a). Effect of medium components on bacteriocin production by Lactobacillus pentosus ST151BR, a strain isolated from beer produced by the fermentation of maize, barley and soy flour. World J. Microbiol. Biotechnol. 20:643-650.

Todorov, S.D., Dicks, L.M.T. (2004b). Screening of lactic-acid bacteria from South African barley beer for production of bacteriocin-like compounds. Folia Microbiol. 49:406-410.

Tomé, E., Teixeira, P., Gibbs, P.A. (2006). Anti-listerial inhibitory lactic acid bacteria isolated from commercial cold smoked salmon. Food Microbiol. 23:399-405.

Tomé, E., Gibbs, P.A., Teixeira, P. (2007). Could modifications of processing parameters enhance the growth and selection of lactic acid bacteria in cold smoked salmon to improve preservation by natural means? J. Food Prot. 70(7):1007-1014.

Truelstrup-Hansen, L. (1995). Quality of chilled, vacuum-packed of cold-smoked salmon. PhD Thesis, Danish Institute of Fisheries. Research, Department of Seafood Research, Technical University Denmark.

Vaughan, E.E., Caplice, E., Looney, R., O’Rourke, N., Coveney, H., Daly, C., Fitzgerald, G.F. (1994). Isolation from food sources, of lactic acid bacteria that produced antimicrobials. J. Appl. Bacteriol. 76:118-123. 
Vaz-Velho, M. (2000). Cold-smoked fish processing and safety. Ph.D Thesis, Escola Superior de Biotecnologia, Universidade Católica PortuguesaPorto, Portugal.

Von Mollendorff, J.W., Todorov, S.D., Dicks, L.M.T. (2006). Comparison of bacteriocins produced by lactic acid bacteria isolated from boza, a cereal-based fermented beverage from the Balkan Peninsula. Curr. Microbiol. 53:209-216.

Yan, T.R., Lee, C.S. (1997). Characterization of a partially purified bacteriocin, Fermentcin B, from Lactobacillus fermentum. Biotechnol. Lett. 19:741-744. 